\title{
Analysis of the Effect of Word Of Mouth, Religiosity and Purchase Decisions of Alcoholic Beverages with Interest as a Mediation Variable
}

\author{
Cahyaning Tiyas $R$ \\ University of Muhammadiyah Surakarta \\ email: b300170167@student.ums.ac.id
}

\begin{abstract}
This study aims to determine the effect of Word Of Mouth, Religiosity, on the decision to purchase alcoholic beverages in the Residency of Surakarta. This study found the factors that influence the decision to purchase alcoholic beverages in the Surakarta Residency. This research uses quantitative methodology to test the hypothesis. Statistical tests and data processing were carried out using Partial Least Square (Smart PLS 3.0). The research findings show that Word of Mouth has a significant and positive effect on purchasing decisions, religiosity has no effect on purchasing decisions, and word of mouth has a positive effect on purchase intention. Religiosity affects buying interest. Buying Interest has an effect on Purchase Decision.
\end{abstract}

Keywords: Word Of Mouth, Religiosity, Purchase Decision,

\section{INTRODUCTION}

In the current development of economic activity, a number of new products and services have emerged. In the era of rapid development and advancement of technology and science, competition between companies to be able to market their products and services is also getting higher. With intense competition in the business world, companies are required to have a competitive advantage in order to be able to compete with other companies in global business (Foster and Johansyah, 2019).

Marketing seeks to identify the needs and wants of target market consumers and how to satisfy them through the exchange 
process while maintaining all parties and goals related to the interests of the company Tampinongkol et al. (2018).

According to Tampinongkol et al. (2018) Word of mouth is word of mouth communication that has the power as a simple form of promotion or advertisement (Prasad et al., 2017). Word of mouth does not require such a large cost, but can get good effectiveness (Susanti \& Wulandari, 2021). Word of mouth is very effective in increasing sales, but the product must have advantages so that consumers feel satisfied and form positive information about the product and start informing others (Danisa et al., 2017; Febriandika et al., 2020; Syahrivar et al., 2018)

The trade in alcoholic beverages is currently attracting many consumers from various circles, not only the upper economic class and the lower middle class economy, even teenagers who are fans of consuming alcoholic beverages. The circulation of alcoholic beverages in Indonesia at this time is quite extensive because in almost every region in Indonesia. The circulation of these drinks seems to never end because the number of alcoholic drink lovers is not small, causing the demand for alcoholic drinks to continue to occur in order to meet consumer demand.

Recently a lot of marketing has focused on religion and human behavior (Ustaahmetoğlu, 2020; Najiyah \& Febriandika, 2019). In various forms the use of alcohol also touches almost all classes of society, for example wine is considered a drink of the nobility and beer as a drink of the common people, even in many places alcohol is also known as a traditional drink. Although alcohol has been known for thousands of years, however, only after going through a very long history, in the mid-18th century doctors in England discovered the adverse effects of alcohol on health (Personal, 2017).

Based on the Central Statistics Agency in Figure 1, it records the distribution of alcohol use per capita throughout Indonesia in 2015-2018. In 2015 the total consumption recorded throughout Indonesia was 0.48 liters of pure alcohol per person aged 15 years. Total unrecorded consumption is estimated at $25 \%$ of total alcohol consumption throughout Indonesia. Even though Indonesia itself is still at the lowest point of alcohol abuse in the Global Health 
Observatory (GHO-WHO) data, which is recorded at less than 2.5 liters/person/capita, it must be understood that the situation of alcohol problems in Indonesia is very complex. Graph of Alcohol Use by Population Age 15 Years is presented in Figure 1.

Based on Figure 1, alcohol was initially only used as an ingredient for making beverages, but now the use of alcohol has become more widespread, namely as a raw material for various industries such as the cosmetics, pharmaceutical, medical and cigarette industries. Although the use of alcohol by the beverage industry is still dominant, in general, the national consumption of alcohol continues to increase along with the development of industries that use alcohol, this can be seen from the trend of alcohol consumption from year to year in Figure 1.1, which shows an increase in alcohol consumption. Alcohol consumption in the industrial world is recorded as using alcohol for the pest eradication industry, office and school equipment, rubber goods.

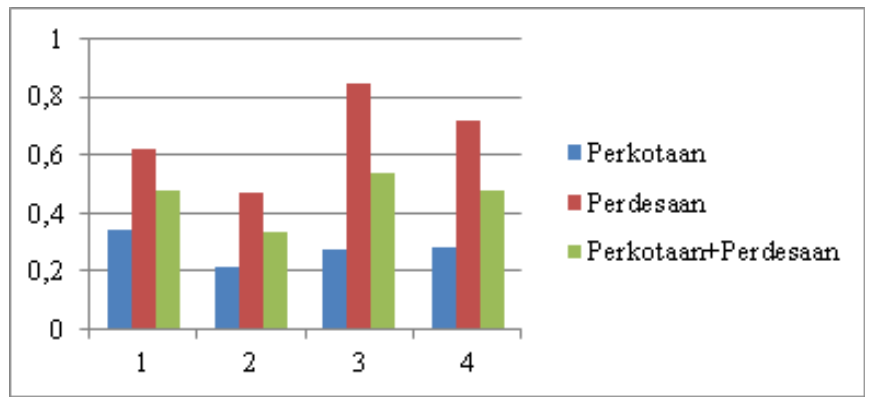

Figure 1. Use of Alcohol Consumption by Population Age 15 Years in the Last Year (Liters per Capita) 2015-2018 in Indonesia

Sumber: Badan Pusat Statistik

According to the 2018 Basic Health Research in Central Java. Preferences describe the proportion of the type of alcohol that most drinkers are interested in. There are 2 groups based on factory and traditional ones, namely beer and wine. The type of alcohol consumed in an area is a sign that the product has a good marketing strategy. Figure 2, shows the level of alcohol consumption by type. 


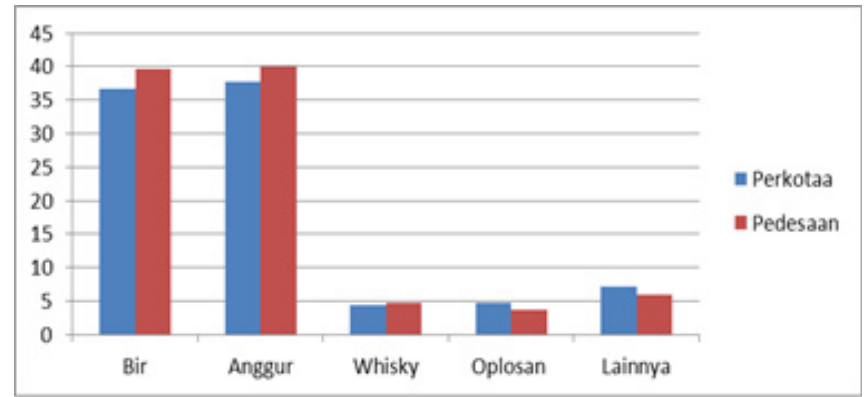

Figure 2 . Proportion of Types of Alcoholic Drinks Drink 15 Years Old and Over in Central Java Province in the last 12 months

From Figure 2, showing the proportion of alcoholic beverages, it can be seen that the circulation of alcoholic beverages in the province of Central Java is still high and is needed either to be used and in demand in consumption, or used in other sectors such as the health, industrial, cosmetic and other sectors. However, from the graph it can be seen that the type of alcohol that is most in demand is alcohol which is used for consumption, so it can be concluded that the interest of the people of Central Java towards alcohol consumption is still high.

From Figure 2, obtained by Basic Health Research, the prevalence of alcohol drinkers in the last 12 months and the last 1 month by district or city in Central Java Province, especially the city of Surakata and Karanganyar district, is as follows, the percentage in Surakarta city of alcohol consumption in the last 12 months was recorded $3,7 \%$ and in the last 1 month recorded $1.7 \%$, while in Karanganyar district alcohol consumption in the last 12 months was recorded at $1.4 \%$ and in the last 1 month recorded $0.6 \%$, at the age of $10-14$ years alcohol consumption in 12 months $0.1 \%$ in the last month and $0.1 \%$ in the last 1 month, and at the age of 15-24 years alcohol consumption in the last 12 months was $4.5 \%$ and in the last 1 month $2.3 \%$.

Based on the description of the problem above, the researcher conducted a study entitled Analysis of the Effect of Word of Mouth and Religiosity on the Decision to Purchase Alcoholic Beverages with Interest as a mediating variable. 


\section{LITERATURE REVIEW Buying Decision}

Schiffman and Kanuk in Akbar and Sunarti, (2018) say that purchasing decisions are the selection of two or more alternative purchasing decision choices, meaning that if someone can make a decision, there must be several alternative choices (Gazzola et al., 2017).

\section{Word Of Mouth}

Word of Mouth has great power to impact consumer buying behavior. Recommendations from trusted friends, associations, and other consumers have the potential to be more trusted than from commercial sources, such as advertisements and sales people (Susanti \& Wulandari, 2021; Syahrivar et al., 2018). For the most part, word of mouth occurs naturally, consumers start by talking about a brand they use to others, this is conveyed by Kloter and Armstrong (2017). Motivated consumers will automatically talk about a product (Danisa et al., 2017).

\section{Religiosity}

According to Sahlan (2012:39) in religiosity (religiousness) is an attitude or awareness that arises based on beliefs or beliefs (Astuty and Umiyati, 2018; Khan \& Kirmani, 2018; Mortimer et al., 2020) someone to a religion (Nora \& Minarti, 2016). Indicators of Islamic religiosity according to El-Menouar and Stiftung (2014) are based on indicators that have been developed by Charles Glock, namely belief, ritual, obedience, experience, knowledge and consequences (Fauzia et al., 2018; Nurhayati \& Hendar, 2019)

\section{Buying Interest}

Based on Nulufi and Murwatiningsih in Shahnaz and Wahyono (2016) interest is a consumer who already has a positive attitude towards a product or brand, will lead to buying interest in that product or brand (Abidin \& Triono, 2020). Some of these understandings, it can be concluded that buying interest is the possibility that consumers will make purchases by seeking 
information from various sources. Consumers have an interest in a product or service but not necessarily consumers will buy the product or service.

\section{Research Hypothesis}

H1: Word of mouth has a positive effect on purchasing decisions

H2: Religiosity has a negative effect on consumer decisions.

H3: Word of Mouth has a positive effect on Buying Interest H4: Religiosity has a positive effect on Buying Interest

H5: Buying Interest Positively Affects Purchase Decisions

H6: Word Of Mouth Positively Affects Purchase Decisions mediated by Buying Interest.

H7: Religiosity has a negative effect on purchasing decisions mediated by buying interest.

\section{METHODS}

This research was conducted in Surakarta. The time of the study was carried out in April 2021. The population in this study was 130 Muslim communities aged over 17 years in Karisidenan Surakarta. The data collection technique used in this study is by distributing questionnaires in the form of a google form to the intended respondents to obtain accurate data. Data analysis method. Hypothesis testing in this study uses the Structural Equation Model (SEM) data analysis method with Partial Least Square (PLS). The implementation of PLS-SEM goes through two stages, the first stage is to evaluate the reliability and validity of the measurement, then the second stage is to evaluate the internal workings of the PLS-SEM model.

\section{RESULTS AND DISCUSSION Structural Model Testing (Inner Model)}

Inner model shows the power of estimation between latent variables or constructs. In this study, the results of the path coefficient test, goodness of fit test and hypothesis testing will be explained. In the tests carried out on the Inner model, the hypothesis can be accepted or rejected. 


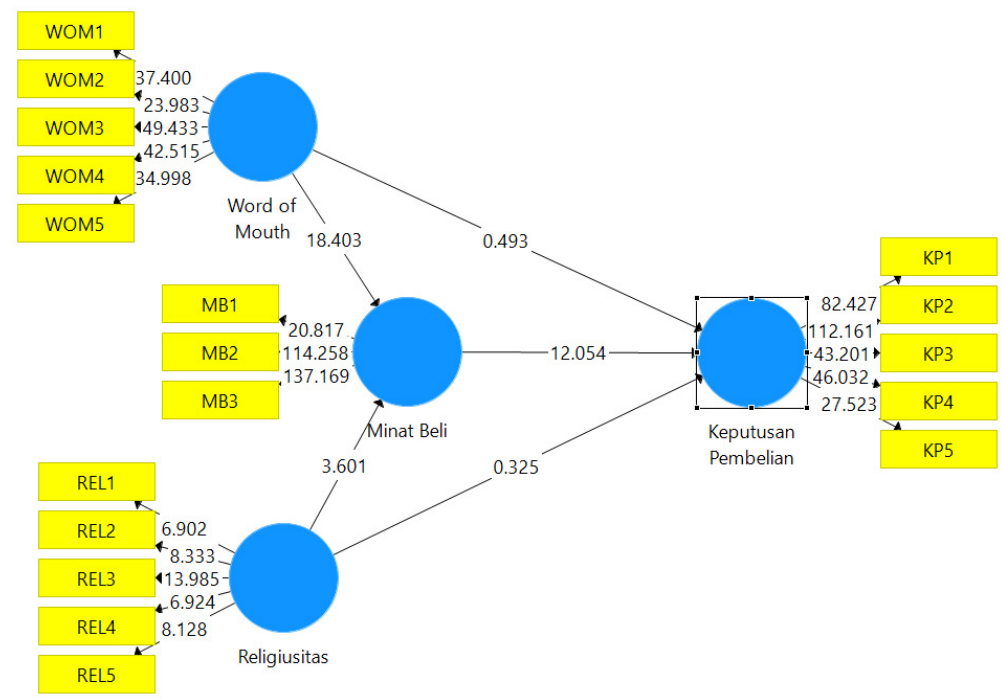

Figure 3. Model Inner

Inner model analysis has several stages before the results of the hypothesis are declared accepted or rejected, with some of these stages to ensure the model is feasible to be tested or not just to influence either directly or indirectly in this study in accordance with Figure 1.4 Inner Model presented above.

\section{R Square Analysis}

$\mathrm{R}$-square is a measure of the proportion of changes in the value of the dependent variable, which can be explained by the independent variable, to predict the quality or goodness of a model. This analysis uses a mediating variable, which means that the value of $r$ square uses the value of $r$ square that has been judged ( $r$ square adjusted), meaning that each additional variable will not necessarily increase the resulting research model.

Table 1. R Square Result

\begin{tabular}{ccc}
\hline Model & R Square & R Square Adjusted \\
\hline Purchase Decision & 0,816 & 0,812 \\
Purchase Intention & 0,727 & 0,722 \\
\hline
\end{tabular}

Sumber: 2021 Data Collection Analysis 
The results obtained in this study indicate that in the buying interest model, an adjusted $r$ square value of 0.722 means that the $r$ square value $>0.7$ means the research model is substantial and the contribution made to the word of mouth and religiosity variable model in explaining buying interest is $72,2 \%$ and the remaining $28.8 \%$ is influenced by other independent variables.

While in the purchasing decision model, the $\mathrm{r}$ square adjusted value of 0.812 means that $r$ square $>0.7$ means that this research model is also substantial and the contribution made to the word of mouth variable model, religiosity and buying interest in explaining purchasing decisions is $81.2 \%$ and the remaining $18.8 \%$ is influenced by other independent variables.

\section{Goodness of Fit Analysis}

These results are to see the model produced in this study is considered feasible or not. The amount of this test is seen from the resulting $\mathrm{Q}$ square value.

Table 2. Q square Result

\begin{tabular}{cc}
\hline Hasil model & Nilai $^{\mathbf{2}}=(\mathbf{1}-\mathbf{S S E} / \mathbf{S S O})$ \\
\hline Purchase decision & 0,649 \\
\hline Purchase intention & 0,561 \\
\hline
\end{tabular}

Sumber: 2021 Data Collection Analysis

The results of the analysis obtained above indicate that the value of q square in the buying interest model is 0.561 , meaning Q square $>0$ so that the buying miant model on the word of mouth and religiosity variables has a relevant predictive and produces a strong model because the value of q square $>0.35$.

While the value of q square in the purchasing decision model is 0.649 , which means $\mathrm{Q}$ square $>0$ so that the buying miant model on the word of mouth, religiosity and buying interest variables has a relevant predictive and produces a strong model because the value of q square $>0.35$. 


\section{Hypothesis Analysis}

Hypothesis analysis is a test carried out to prove the hypothesis is accepted or rejected. The results of this analysis will be able to know the significant influence directly or indirectly between the independent variables on the dependent. In Smart PLS the results of this analysis by looking at the path coefficient and indirect effect.

Table 3. Path Analysis (Direct Effect)

\begin{tabular}{lcccc}
\hline \multicolumn{1}{c}{ Model } & $\begin{array}{c}\text { Original } \\
\text { Sample (O) }\end{array}$ & $\begin{array}{c}\text { T Statistics }(\mid \mathbf{O} / \\
\text { STDEV } \mid)\end{array}$ & P Values \\
\hline $\begin{array}{l}\text { Purchase } \\
\text { Decision }\end{array}$ & 0,873 & 12,054 & 0,000 \\
Religiosity -> Purchase Decision & 0,013 & 0,325 & 0,745 \\
Religiosity -> Purchase Intention & $-0,155$ & 3,601 & 0,000 \\
Word of Mouth -> Purchase Decision & 0,040 & 0,493 & 0,623 \\
Word of Mouth -> Purchase Intention & 0,810 & 18,403 & 0,000 \\
\hline
\end{tabular}

Sumber: 2021 Data Collection Analysis

\section{Regression Analysis}

This analysis is to see how much influence the independent variable has on the dependent. In media testing there are 2 basic regression models formed in this study, with:

$\mathrm{MB}=-0,155 \mathrm{REL}+0,810 \mathrm{WOM}+\mathrm{e}$

Interpretation:

1) REL coefficient of -0.155 indicates the higher the level of consumer religiosity, the consumer's buying interest will decrease..

2) The WOM coefficient of 0.810 indicates that the stronger word of mouth spread among consumers, the stronger their buying interest will be. 
$\mathrm{KP}=0,013 \mathrm{REL}+0,040 \mathrm{WOM}+0,873 \mathrm{MB}$

Interpretation:

1. The REL coefficient of 0.013 indicates that the higher the level of consumer religiosity, the stronger consumer purchasing decisions.

2. The WOM coefficient of 0.040 indicates that the stronger the word of mouth spread among consumers, the stronger the purchase decision will be.

3. The MB coefficient of 0.873 indicates that the stronger the consumer's buying interest, the stronger the purchasing decision will be.

\section{Direct Effect}

Direct effect is a t-test analysis to see the direct significant effect between the independent variables on the dependent. In Smart PLS this analysis is tested by comparing $\mathrm{t}$ table and $\mathrm{t}$ table with a level of sig $5 \%$ is 1.96.

1. Religiosity - Buying Interest

The results of the analysis that can be disclosed are the $t$ statistic value of 3.601 and $p$ value of 0.000 means $\mathrm{t}$ statistic $>\mathrm{t}$ table 1.96 or $\mathrm{p}$ value 0.000 $<0.05$ then Ho is rejected, meaning that religiosity has a significant effect on consumer buying interest.

2. Word of Mouth - Buying Interest

The results of the analysis that can be disclosed are the t-statistical value of 318.403 and p-value 0.000 means t-statistic $>\mathrm{t}$-table 1.96 or $\mathrm{p}$-value 0.000 $<0.05$ then Ho is rejected, meaning that word of mouth has a significant effect on consumer buying interest.

3. Religiosity - Purchase Decision

The results of the analysis that can be disclosed are the $t$ statistic value of 0.325 and $p$ value of 0.745 meaning $t$ statistic $<\mathrm{t}$ table 1.96 or $\mathrm{p}$ value $0.745>$ 0.05 then Ho is accepted meaning that religiosity has no significant effect on consumer purchasing decisions. 
4. Word of Mouth - Purchase Decision

The results of the analysis that can be disclosed are the $t$-statistical value of 0.493 and $p$-value of 0.623 , meaning t-statistic $<\mathrm{t}$-table 1.96 or p-value $0.623>$ 0.05 , then Ho is accepted, meaning that religiosity has no significant effect on consumer purchasing decisions.

5. Purchase intention - Purchase Decision

The results of the analysis that can be disclosed are the $t$-statistical value of 12.054 and $p$-value 0.000 , meaning t-statistic $>\mathrm{t}$-table 1.96 or $\mathrm{p}$-value 0.000 $<0.05$, then Ho is rejected, meaning that consumer buying interest has a significant effect on consumer purchasing decisions.

\section{Indirect Effect}

The indirect effect in this study is to analyze the indirect significant effect between the independent variables on the dependent variable by using mediating or intermediary variables. In Smart PLS this analysis is tested by comparing $t$ table and t table with a level of sig $5 \%$ is 1.96 .

Tabel 4. Indirect Effect

\begin{tabular}{llll}
\hline \multicolumn{1}{c}{ Model } & \multicolumn{1}{c}{$\begin{array}{c}\text { Original } \\
\text { Sample (O) }\end{array}$} & $\begin{array}{c}\text { T Statistics } \\
(\mid \mathbf{O} / \text { STDEV } \mid)\end{array}$ & P Values \\
\hline $\begin{array}{l}\text { Purchase Intention -> Purchase Decision } \\
\text { Religiosity -> Purchase Decision }\end{array}$ & $-0,135$ & 3,221 & 0,001 \\
$\begin{array}{l}\text { Religiosity -> Purchase Intention } \\
\text { Word of Mouth -> Purchase Decision }\end{array}$ & 0,707 & 11,115 & 0,000 \\
Word of Mouth -> Purchase Intention & & & \\
\hline
\end{tabular}

Sumber: 2021 Data Collection Analysis

The results of the analysis show that the mediating coefficient of buying interest between religiosity and purchasing decisions is -0.135 with a t statistic of 3.221 or $p$ value of 0.001 meaning that $t$ statistic $>t$ table 1.96 or $\mathrm{p}$ value $<0.05$, it can be explained that buying interest 
mediates negatively significantly. between religiosity on purchasing decisions.

The mediation coefficient of buying interest between word of mouth on purchasing decisions is 0.707 with a $t$ statistic of 11.115 or $p$ value 0.000 meaning that $t$ statistics $>\mathrm{t}$ table 1.96 or $\mathrm{p}$ value $<0.05$, it can be explained that buying interest mediates positively significantly between word of mouth. mouth on purchasing decisions.

\section{The Influence of Word Of Mouth on Purchase Decisions}

Word of mouth has a positive and insignificant effect on purchasing decisions. This illustrates that the word of mouth that someone does will not have a strong influence on the decisions made by consumers themselves (Danisa et al., 2017; Prasad et al., 2017).

This means that word of mouth is not able to influence consumers to decide to buy alcoholic beverage products because some consumers make purchasing decisions not because of positive stories (Shahrivar et al., 2018), recommendations and invitations but because the product is seen from the side of Sharia in religious orders, alcoholic beverage products are prohibited drinks and the samples taken are Muslim communities who have an awareness of carrying out religious orders so that if other people talk about alcoholic products positively, they will not be affected by the decision to buy the product (Susanti \& Wulandari, 2021).

\section{The Influence of Religiosity on Consumer Decisions}

The results of the answers in this study, which mostly answered strongly disagreed in religiosity, meant that high religiosity did not affect the decision of the Muslim community in buying alcoholic beverages (Bukhari et al., 2019). In addition, people who prioritize religion more influence their purchasing power (Khan \& Kirmani, 2018). That is, the more religious people are, the less likely they are to follow up on new buying opportunities (Astuty and Umiyati, 2018) that arise during their grocery shopping journey (Ustaahmetoğlu, 2020). 


\section{The Influence of Word Of Mouth on Buying Interest}

The delivery of information by word of mouth carried out by one individual to another based on positive experiences with a product, service, or company (Prasad et al., 2017). A positive experience is allegedly an experience that a person gets either directly or indirectly with the use of a product, service, or company accompanied by satisfaction or fulfillment of the individual's expectations (Syahrivar et al., 2018).

So that word of mouth that occurs positively will give the impression of a positive and convincing experience to people so that this will build their buying interest well (Susanti \& Wulandari, 2021).

\section{The Influence of Religiosity on Buying Interest}

Religiosity is found in various aspects of life, including social and economic aspects, one of which is when choosing to consume food and drinks, namely there are rules regarding food and drinks that are allowed to be consumed and those that are not (Nora \& Minarti, 2016). Religiosity is the main consideration that causes repurchase decisions by consumers (Astuty and Umiyati, 2018; Nurhayati \& Hendar, 2019) one of which in buying halal food says religiosity is the main factor that influences a Muslim consumer in determining the food they want to consume ( Bukhari et al., 2019; Khan \& Kirmani, 2018; Mortimer et al., 2020).

\section{The Influence of Buying Interest on Consumer Decisions}

Product purchase is a tangible form of action from consumer buying interest. When consumers have an interest in buying a product, consumers will make a decision to purchase a product through a purchasing decision process with indicators set for the purpose of buying the product.

Provide recommendations to others and make repeat purchases. Eliza et al. (2018) states that consumer buying interest has a significant effect on purchasing decisions, meaning that the higher consumers' buying interest in a product, the higher the purchase decision of the product. So that the coughing interest 
will produce a strong decision in buying the product (Abidin \& Triono, 2020).

\section{The Influence of Word Of Mouth on Purchase Decisions mediated by Buying Interest}

A word of mouth communication will greatly affect consumers who are interested in suggestions from people who have had experience with the product (Danisa et al., 2017). In fact, someone will trust the opinions of others who have experience with a product more than the advertisements and promotional media launched by the company (Syahrivar et al., 2018). With word of mouth communication (Susanti \& Wulandari, 2021) someone will easily believe in a product that can form an interest in buying and later is expected to have an impact on purchasing decisions by consumers.

\section{The Influence of Religiosity on Purchase Decisions mediated by Buying Interest}

In economic activities, especially the purchase of a product, religiosity is also accompanied by an interest in buying goods, so that the avoidance of illicit goods is a driving force for purchasing decisions (Nurrachmi and Setiawan, 2020). High level of awareness in carrying out religious orders (Bukhari et al., 2019; Nora \& Minarti, 2016)

Religiosity is a form of practice in carrying out Islamic law (Mortimer et al., 2020). With the high level of religiosity that exists in the community, it will increase interest (Mujaddid and Nugroho, 2019; Nurhayati \& Hendar, 2019). However, public awareness of religious orders makes the community's religious orders become guidelines that should not be violated (Astuty and Umiyati, 2018) so that it will make the decline in buying interest stronger which has an impact on a strong decline in consumer purchasing decisions for alcoholic beverages.

\section{CONCLUSION}

These results indicate that in terms of religiosity, producers need to find new places or strategies so that these products can 
still be sold because it is impossible for a consumer segment with high religiosity to want to buy alcoholic beverage products, meaning that the product may not be sold as a drink but as an alcoholic product to make healing wound.

Word of mouth, manufacturers still allow a minimum product with alcohol to be sold if the product is able to give a good impression to others, then the product will be discussed from person to person so as to increase buying interest and in the long term consumer decisions will be strong in buying beverage products. alcoholic.

\section{REFERENCES}

Abidin, Z., \& Triono, L. D. (2020). Fresh frozen fish consumer behavior: Effect of the mix and trust marketing on buying interest, purchase decision and customer satisfaction in E-commerce, silly fish Indonesia. IOP Conference Series: Earth and Environmental Science, 493(1). https://doi. org/10.1088/1755-1315/493/1/012041

Akbar, M. J. C., \& Sunarti. (2018). Pengaruh Electronic Word Of Mouth Terhadap Keputusan Pembelian (Survei Pada Konsumen Restoran Sushi Tei Kelapa Gading). Jurnal Administrasi Bisnis (JAB), Vol. 60(No. 3), H. 45-51.

Astuty, P., \& Umiyati, U. (2018). Inluence Of Religiosity Towards The Saving Interest At Islamic Banking With The Knowledge Of The People As Moderator Variable (Case Study on The People of South Tanggerang City). Ikonomika, 3(1), 1. https://doi.org/10.24042/febi.v3i1.2229

Arifin,Zainal.,Sunarti.(2015).Analisis Strategi Pemasaran

Untuk Meningkatkan Daya Saing.Jurnal Administrasi Bisnis.29(1).

Augustinah, F., \& Dwijosusilo, K. (2018). Pengaruh Label Halal

Dan Religiusitas Terhadap Minat Beli Dan Keputusan Pembelian. Jurnal Sketsa Bisnis, 5(1), 49-59.

Budiaji, W. (2013). Skala Pengukuran Dan Jumlah Respon Skala Likert (The Measurement Scale And The Number 
Of Responses In Likert Scale). Jurnal Ilmu Pertanian Dan Perikanan, 2(2), 127-133. Http://Umbidharma.Org/Jipp

Bukhari, S. F. H., Woodside, F. M., Hassan, R., Shaikh, A. L., Hussain, S., \& Mazhar, W. (2019). Is religiosity an important consideration in Muslim consumer behavior: Exploratory study in the context of western imported food in Pakistan. Journal of Islamic Marketing, 10(4), 1288-1307. https:// doi.org/10.1108/JIMA-01-2018-0006

Danisa, T. C. E., Istiyanto, B., \& Ardyana, E. (2017). The Effect of Electronic Word of Mouth, Trust, Perceived Risk, and Site Quality on Transactions using E-Commerce. International Conference "Sustainable Development Goals 2030 Challenges and Its Solutions, 1(August), 191-208. www. startupbisnis.com

Dewi, M. K., \& Winarningsih. (2019). Pengaruh Disiplin Kerja, Motivasi Kerja,Lingkungan Kerja Terhadap Kinerja Karyawanpt. Cpo Sidoarjo.

Eliza, R., Sinaga, M., \& Kusumawati, A. (2018). Pengaruh Youtube Beauty Vlogger Terhadap Minat Beli Konsumen Dan Dampaknya Terhadap Keputusan Pembelian Produk (Studi Pada Pengguna Kosmetik Maybelline Di Indonesia). Jurnal Administrasi Bisnis (JAB)|Vol, 63(1), 187-196.

Febriandika, N. R., Millatina, A. N., \& Herianingrum, S. (2020, January). Customer E-Loyalty of Muslim Millennials in Indonesia: Integrated Model of Trust, User Experience and Branding in E-Commerce Webstore. In Proceedings of the 2020 11th International Conference on E-Education, E-Business, E-Management, and E-Learning (pp. 369-376).

Fitria Nurma Sari, F., \& Anwar, M. (2018). Pengaruh Tingkat Religiusitas Santri Pondok Pesantren Darussalam Kediri Terhadap Minat Menabung Di Perbankan Syariah. Jurnal Ekonomi Islam, 1(1), 25-35.

Foster, B., \& Johansyah, M. D. (2019). The effect of product quality and price on buying interest with risk as intervening variables (study on Lazada.com site users). International 
Journal of Innovation, Creativity and Change, 9(12), 6678.

Gazzola, P., Colombo, G., Pezzetti, R., \& Nicolescu, L. (2017). Consumer empowerment in the digital economy: Availing sustainable purchasing decisions. Sustainability (Switzerland), 9(5), 1-19. https://doi.org/10.3390/ su9050693

Ghazali, Imam. 2013. Aplikasi Analisis Multivariate Dengan Program IBM SPSS 21. Semaranag: Badan Penerbit Universitas Diponegoro.

Hidayanti, A. A., \& Masyhudi, L. (2020). Pengaruh Electronic Word Of Mouth, Daya Tarik Dan Lokasi Terhadap Minat Berkunjung Wisatawan Di Desa Tete Batu Kabupaten Lombok Timur. Jurnal Inovasi Penelitian, 1(2), 129-144. Https://Doi.Org/10.47492/Jip.V1i2.160

Imamuddin, M., Syahrul, S., \& Dantes, R. (2020). Pengaruh Label Halal Dimoderasi Religiusitas Terhadap Keputusan Pembelian Produk Kemasan Oleh Mahasiswa PTKIN SeSumatera Barat. KABILAH : Journal Of Social Community, 5(1), 14-25. Https://Doi.Org/10.35127/Kbl.V5i1.3884

Khan, M. N., \& Kirmani, M. D. (2018). Role of religiosity in purchase of green products by Muslim students: Empirical evidences from India. Journal of Islamic Marketing, 9(3), 504-526. https://doi.org/10.1108/JIMA-04-2017-0036

Liyas, J. N., \& Primadi, R. (2017). Pengaruh Disiplin Kerja Terhadap Kinerja Karyawan Pada Bank Perkreditan Rakyat. Al Masraf: Jurnal Lembaga Keuangan Dan Perbankan, 2(1), 1-10. Https://Doi.Org/10.1016/J.Nanoen.2012.08.008

Mahendrayasa, A. (2014). Pengaruh Word Of Mouth Terhadap Minat Beli Serta Dampaknya Pada Keputusan Pembelian (Survei Pada Mahasiswa Pengguna Kartu Selular GSM Âim3â Angkatan 2011/2012 Dan 2012/2013 Fakultas Ilmu Administrasi Universitas Brawijaya Malang). Jurnal Administrasi Bisnis S1 Universitas Brawijaya, 12(1), 82799. 
Maisur, Arifin, M. Arfan, \& M.Shabri. (2015). Pengaruh Prinsip Bagi Hasil, Tingkat Pendapatan, Religiusitas Dan Kualitas Pelayanan Terhadap Keputusan Menabung Nasabah Pada Bank Syariah Di Banda Aceh. Jurnal Magister Akuntansi Pascasarjana, 4(2), 1-8.

Marlius, D. (2018). Pengaruh Bauran Pemasaran Jasa Terhadap Minat Nasabah Dalam Menabung Pada Bank Nagari Cabang Muaralabuh. 12-22. Https://Doi.Org/10.31227/ Osf.Io/Vdqgx

Mas, A., Hamdy, M. I., \& Safira, M. D. (2019). Place, Promotion ) Pada Pt. Haluan Riau. Jurnal Hasil Penelitian Dan Karya Ilmiah Dalam Bidang Teknik Industri, 5(2), 79-86.

Mortimer, G., Fazal-e-Hasan, S. M., Grimmer, M., \& Grimmer, L. (2020). Explaining the impact of consumer religiosity, perceived risk and moral potency on purchase intentions. Journal of Retailing and Consumer Services, 55(February), 102115. https://doi.org/10.1016/j.jretconser.2020.102115

Mujaddid, F., \& Nugroho, P. T. A. (2019). Pengaruh Pengetahuan, Reputasi, Lingkungan Dan Religiusitas Terhadap Minat Pelajar Sekolah Menengah Kejuruan Prodi Perbankan Syariah Dalam Menabung Di Bank Syariah. Jurnal Ekonomi Islam, 10(1), 14-37.

Mulyandi, M. R., \& Sani, E. P. (2019). Pengaruh E Marketing Mix Terhadap Minat Beli Konsumen (Studi Kasus Pada E Commerce Di Indonesia). Jurnal Iimiah Teknologi, 3(1), 41-49. Nanda Bella Fidanty Shahnaz, W. (1911). Faktor Yang Mempengaruhi Minat Beli Konsumen Di Toko Online. Management Analysis Journal, 32(2), 254-255. Https://Doi.Org/10.1103/Physrevseriesi.32.254

Najiyah, F., \& Febriandika, N. R. (2019, October). The Role of Government in the Zakat Management: The Implementation of A Centralized and Decentralized Approach (Comparative Study in Indonesia and Malaysia). In 2018 International Conference on Islamic Economics and Business (ICONIES 2018) (pp. 290-292). Atlantis Press. 
Nasrullah, M. (2015). Islamic Branding, Religiusitas Dan Keputusan Konsumen Terhadap Produk. Jurnal Hukum Islam, 13(2), 79. Https://Doi.Org/10.28918/Jhi.V13i2.487

Nora, Liza \& Minarti, N. S. (2016). The Role of Religiosity, Lifestyle, Attitude as Determinant Purchase Intention. The 2nd International Multidisciplinary Conference 2016, October 2016, 135-148.

Nurhayati, T., \& Hendar, H. (2019). Personal intrinsic religiosity and product knowledge on halal product purchase intention: Role of halal product awareness. Journal of Islamic Marketing, 11(3), 603-620. https://doi.org/10.1108/JIMA11-2018-0220

Nurrachmi, I., \& Setiawan, S. (2020). Pengaruh Religiusitas, Kepercayaan, Dan Kepuasan Terhadap Keputusan Pembelian Ulang Produk Halal. IQTISHADIA: Jurnal Ekonomi Dan Perbankan Syariah, 7(2), 126-137. Https:// Doi.Org/10.1905/Iqtishadia.V7i2.3521

Pamungkas, B. A. (2017). Pengaruh Promosi Di Media Sosial Dan Word Of Mouth Terhadap Keputusan Pembelian (Studi Kasus Pada Kedai Bontacos, Jombang). Jurnal Komunikasi, 10(2), 145. Https://Doi.Org/10.21107/Ilkom.V10i2.2518

Prasad, S., Gupta, I. C., \& Totala, N. K. (2017). Social media usage, electronic word of mouth and purchase-decision involvement. In Asia-Pacific Journal of Business Administration (Vol. 9, Issue 2). https://doi.org/10.1108/ APJBA-06-2016-0063

Pratiwi, Y. R. (2017). Pengaruh Word Of Mouth Communication Terhadap Keputusan Pembelian Konsumen Pada Boardgame Lounge Smart Cafe Pekanbaru. Jom Fisip, 4(1), 1-15.

Prayoga, I., \& Rachman, M. (2020). Setiap Manusia Memiliki Kebutuhan Hidupnya Masing-Masing . Salah Satu Kebutuhan Hidup Manusia Yaitu Makan Dan Minum . Makan Dan Minum Merupakan Kebutuhan Dasar Yang Harus Dipenuhi Setiap Harinya Oleh Manusia, Oleh Karna Itu Bisnis Dibidang Makanan Dan Mi. 1(5). 
Pribadi, E. T. (2017). Penyalahgunaan Alkohol Di Indonesia: Analisis Determinan, SWOT, Dan CARAT. Journal Of Health Science And Prevention, 1(1), 22-37.

Purbayanti, D., \& Saputra, N. A. R. (2017). Efek Mengkonsumsi Minuman Beralkohol Terhadap Kadar Triglisrida. Jurnal Surya Medika, 3(1), 75-81. Https://Doi.Org/10.33084/Jsm. V3i1.214

Raniawati Rachman Dan Totok Wahyu Abadi. (2017). Komunikasi Word Of Mouth Dan Keputusan Pembelian Batik Bangkalan. Jurnal Aspikom, Volume 3(Nomor 2), Hlm 285-295.

Rohmatun, K. I., \& Dewi, C. K. (2017). Pengaruh Pengetahuan Dan Religiusitas Terhadap Niat Beli Pada Kosmetik Halal Melalui Sikap. Journal Ecodemica, 1(1), 27-35. Https:// Ejournal.Bsi.Ac.Id/Ejurnal/Index.Php/Ecodemica/Article/ View/1420

Romdhoni, A. H., \& Sari, D. R. (2018). Pengaruh Pengetahuan, Kualitas Pelayanan, Produk, Dan Religiusitas Terhadap Minat Nasabah Untuk Menggunakan Produk Simpanan Pada Lembaga Keuangan Mikro Syariah. Jurnal Ilmiah Ekonomi Islam, 4(02), 136. Https://Doi.Org/10.29040/Jiei. V4i02.307

Sarah, S. F., \& Artanti, Y. (2020). Pengaruh Religiusitas Dan Kelompok Referensi Terhadap Keputusan Pembelian. BISNIS : Jurnal Bisnis Dan Manajemen Islam, 8(1), 37. Https://Doi.Org/10.21043/Bisnis.V8i1.6732.

Siddiq, A. (2014). Pengaruh Pengetahuan Produk Dan Citra Merek Terhadap Keputusan Pembelian Laptop Samsung (Survey Pada Konsumen Itklik Jakarta). Jurnal Manajemen Pemasaran, 2(2), 1-7. Https://Doi.Org/10.9744/ Pemasaran.8.2.47-54

Solihin, D. (2020). Pengaruh Kepercayaan Pelanggan Dan Promosi Terhadap Keputusan Pembelian Konsumen Pada Online Shop Mikaylaku Dengan Minat Beli Sebagai Variabel Intervening. Jurnal Mandiri : Ilmu Pengetahuan, Seni, Dan 
Teknologi, 4(1), 38-51. Https://Doi.Org/10.33753/Mandiri. V4i1.99

Sudarti, K. (2019). Merek Terhadap Minat Beli Ulang. 20(2), $48-61$.

Supriyanto, M., \& Taali, M. (2018). Pengaruh Bauran Pemasaran (Marketing Mix) Terhadap Pengambilan Keputusan Menginap Di The Sun Hotel Madiun.

Susanti, N. F., \& Wulandari, R. (2021). How Does the Electronic Word of Mouth (Ewom) Build Brand Trust in Increasing Buying Interest During the. 5(03), 70-83.

Syahrivar, J., \& Ichlas, A. M. (2018). The Impact of Electronic Word of Mouth (E-WoM) on Brand Equity of Imported Shoes: Does a Good Online Brand Equity Result in High Customers' Involvements in Purchasing Decisions? The Asian Journal of Technology Management (AJTM), 11(1), 57-69. https://doi.org/10.12695/ajtm.2018.11.1.5

Tampinongkol, V. M., Mandagie, Y., Sam, U., \& Manado, R. (2018). Analisis Pengaruh Word Of Mouth, Kualitas Produk Dan Brand Image Terhadap Keputusan Pembelian Sepatu Converse Di Manado Town Square. Jurnal EMBA: Jurnal Riset Ekonomi, Manajemen, Bisnis Dan Akuntansi, 6(4), 2008-2017. Https://Doi.Org/10.35794/Emba.V6i4.20930

Ustaahmetoğlu, E. (2020). The influence of different advertisement messages and levels of religiosity on attitude and purchase intention. International Journal of Islamic and Middle Eastern Finance and Management, 13(2), 339-356. https:// doi.org/10.1108/IMEFM-02-2019-0064

Widodo, M. S., \& Wariati, A. (2016). Pengaruh Disiplin Kerja, Komitmen Organisasi Dan Lingkungan Kerja Terhadap Kinerja Karyawan (Study Kasus Bagian Sortir PT. TIKI) Di Sukoharjo. 2(1), 105-113. 